\title{
A novel porcine mRNA differentially expressed in the Longissimus muscle tissues from Meishan and Large White pigs are associated with carcass traits and meat quality
}

\author{
G.Y. Liu ${ }^{1,3}$ and Y.Z. Xiong ${ }^{2}$ \\ ${ }^{1}$ Key Laboratory of Animal Nutrition and Feed of Yunnan Province, \\ Yunnan Agricultural University \\ Kunming 650201, P.R. China \\ ${ }^{2}$ Key Laboratory of Swine Genetics and Breeding, Ministry of Agriculture, \\ Huazhong Agricultural University \\ Wuhan 430070, P.R. China
}

(Received 2 April 2008; revised version 14 August 2008; accepted 27 October 2008)

\begin{abstract}
The mRNA differential display technique was performed to investigate the differences of gene expression in the Longissimus muscle tissues from Meishan and Large White pigs. One novel mRNA that was differentially expressed was identified through semi-quantitative RT-PCR and the cDNA complete sequence was then obtained using the rapid amplification of cDNA ends (RACE) method. Sequence analysis revealed that this mRNA is not homologous to any known porcine gene. Sequence prediction analysis revealed that the this mRNA is not protein-coding mRNA. Polymorphism analyses revealed that there was a A-G mutation on the position of $490 \mathrm{bp}$ and PCRTaqI-RFLP analyses revealed that Chinese indigenous pig breeds and European pig breeds displayed obvious genotype and allele frequency differences at this locus. Association analyses revealed that this polymorphic locus was significantly associated with the meat $\mathrm{pH}$ of $M$. longissimus dorsi (LD), M. biceps femoris (BF), M. semispinalis capitis (SC), water holding capacity, drip loss rate, meat colour value $M$. longissimus dorsi (LD), and estimated lean meat percentage $(\mathrm{P}<0.05)$.
\end{abstract}

KEY WORDS: pig, mRNA differential display, RACE

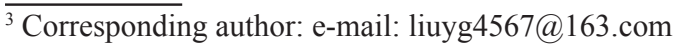




\section{INTRODUCTION}

The mRNA differential display first described by Liang and Pardee (1992) is a fast, and efficient method for isolating and characterizing altered gene expression in different cell types. It was statistically shown that 80-120 primer combinations would be sufficient to cover all the transcript populations in the cell (Liang et al., 1993). This technique possesses the following advantages over other similar techniques: it is based on simple and established methods, more than two samples can be compared simultaneously and only a small amount of starting material is needed (Yamazaki and Saito, 2002) .

Chinese indigenous pig breeds such as Meishan, Erhualian and Tongcheng often have valuable traits such as disease resistance, high fertility, good maternal qualities, unique product qualities, longevity and adaptation to harsh conditions. Pig breeds in Europe such as Large White, Landrace, Duroc possess the good achievements in growth rate, high lean rate, especially, the introduced pigs have higher lean meat rate and feed conversion efficiency, whereas Chinese indigenous pigs have more fat deposition and superior meat quality (Pan et al., 2003) . Phenotypic variances are mainly determined by the genetic differences. So that detecting the genetic differences between Chinese indigenous pig breeds and European pig breeds or finding out the differentially expressed genes between Chinese indigenous pig breeds and European pig breeds which determine these phenotypic variances is necessary for pig breeders.

Our present study was carried out with the mRNA differential display technique to isolate the differentially expressed genes or mRNAs in the Longissimus dorsi muscle tissues from one Chinese indigenous pig breed - Meishan and one European pig breed - Large White pigs.

\section{MATERIAL AND METHODS}

\section{Animals and sample preparation}

For mRNA differential display Large White and Meishan pigs, the two purebred populations were constructed in December, 2002. The Longissimus dorsi muscle samples were collected from 180-day-old pigs (for each breed, five male and five female) slaughtered in March, 2003 and frozen in liquid nitrogen. These Longissimus dorsi muscle samples would be used to perform the mRNA differential display.

For polymorphism analyses blood samples were collected from 225 unrelated animals belonging to six swine populations presented in Table 1. Genomic DNA isolated from the blood samples would be used to perform the polymorphism analyses. 
Table 1 . The information of 225 unrelated pigs from 6 populations

\begin{tabular}{llcc}
\hline \multirow{2}{*}{ Breed } & \multirow{2}{*}{ Sampling location } & \multicolumn{2}{c}{ Sample size } \\
\cline { 3 - 4 } & & 20 & female \\
\hline Large White & Hubei Jingping pig breeding farm & 20 & 20 \\
Landrace & Hubei Jingping pig breeding farm & 20 & 20 \\
Meishan & Hubei Jingping pig breeding farm & 21 & 20 \\
Bamei & Longdong region, Gansu Province & 20 & 19 \\
Tongcheng & Hubei Tongcheng pig conservation farm & 12 & 20 \\
Huainan & Henan Province & & 13 \\
\hline
\end{tabular}

For association analyses $300 \mathrm{~F} 2$ pigs from Large White $\times$ Meishan were slaughtered in Autumn, 2000 and 2003, when these pigs were 180-day-old. The growth, carcass and meat quality traits presented in Table 2 were recorded according to the method of Xiong and Deng (1999). Genomic DNA was isolated from blood white cells and DNA extraction procedure was described by Sambrook et al. (1989). The growth, carcass and meat quality traits data and Genomic DNA would be used to perform association analyses.

Table 2. Abbreviations of names for the productive traits in pig resource family

\begin{tabular}{clll}
\hline No. & Abbreviations & \multicolumn{1}{c}{ Names } & Unit \\
\hline 1 & LC1 & Carcass length (maximum) & $\mathrm{cm}$ \\
2 & LC2 & Carcass length (minimum) & $\mathrm{cm}$ \\
3 & ELMP & Estimated lean meat percentage & $\%$ \\
4 & EBFT1 & Estimated backfat thickness at last rib & $\mathrm{mm}$ \\
5 & EBFT2 & Estimated backfat thickness at last 3-4th rib & $\mathrm{mm}$ \\
6 & FMW & Fat meat weight & $\mathrm{kg}$ \\
7 & LMP & Lean meat percentage & $\%$ \\
8 & FMP & Fat meat percentage & $\%$ \\
9 & LMW & Lean meat weight & $\mathrm{kg}$ \\
10 & LFW & Leaf fat weight & $\mathrm{kg}$ \\
11 & BFT1 & Backfat thickness at shoulder & $\mathrm{cm}$ \\
12 & BFT2 & Backfat thickness at thorax-Waist & $\mathrm{cm}$ \\
13 & BFT4 & Backfat thickness at 6-7th thorax & $\mathrm{cm}$ \\
14 & MCV (BF) & Meat colour value (M. Biceps femoris, BF) & $\%$ \\
15 & MM (BF) & Meat marbling $(M$. Biceps femoris, BF) & - \\
16 & WM (LD) & Water moisture (M. longissimus dorsi, LD) & $\%$ \\
17 & BW & Bone weight & $\mathrm{kg}$ \\
18 & BP & Bone percentage & $\%$ \\
19 & LEW & Loin eye width & $\mathrm{cm}$ \\
20 & LEA & Loin eye area & $\mathrm{cm} \times \mathrm{cm}$ \\
21 & WHC & Water Holding Capacity & $\%$ \\
22 & RATIO & Ratio of lean meat to fat meat & - \\
23 & pH (LD) & Meat pH (M. Longissimus dorsi, LD) & $\mathrm{pH}$ \\
24 & pH (BF) & Meat pH (M. biceps femoris, BF) & $\mathrm{pH}$ \\
25 & pH (SC) & Meat pH (M. semispinalis capitis, SC) & $\mathrm{pH}$ \\
\hline & & &
\end{tabular}


$m R N A$ differential display

The mRNA differential display was performed as that described previously (Liu et al., 2004).

\section{Semi-quantitative RT-PCR}

Semi-quantitative RT-PCR was performed as previously described elsewhere (Liu et al., 2005a,b; Liu and Xiong, 2007). We selected the housekeeping gene G3PDH (glyceraldehyde-3-phosphate dehydrogenase) as the internal control. The control primers used were: 5'-ACCACAGTCCATGCCATCAC-3' (G3PDH 5' primer) and 5'-TCCACCACCCTGTTGCTGTA-3' (G3PDH 3' primer). The following expressed sequence tags (EST) or gene specific primers were used to perform the RT-PCR for identification of the differentially expressed mRNA (mRNA2): 5'- GAATCCGACCGAGAACCA-3' (forward primer1) and 5'AGCCGTGTCTGCAACCTAC-3' (reverse primer1). The $25 \mu \mathrm{l}$ reaction system was: $2 \mu \mathrm{l}$ cDNA (100-500 ng), 5 pmoles each oligonucleotide primer, $2.5 \mu \mathrm{l}$ $2 \mathrm{mmol} / 1 \mathrm{mixed}$ dNTPs, $2.5 \mu \mathrm{l} 10 \times$ Taq DNA polymerase buffer, $2.5 \mu 125 \mathrm{mmol} / 1$ $\mathrm{MgCl}_{2}, 1.0$ units of Taq DNA polymerase, and finally add sterile water to volume $25 \mu$. The PCR program initially started with a $94^{\circ} \mathrm{C}$ denaturation for $4 \mathrm{~min}$, followed by 25 cycles of $94^{\circ} \mathrm{C} / 50 \mathrm{~s}, 58^{\circ} \mathrm{C} / 50 \mathrm{~s}, 72^{\circ} \mathrm{C} / 50 \mathrm{~s}$, then $72^{\circ} \mathrm{C}$ extension for $10 \mathrm{~min}$, finally $4^{\circ} \mathrm{C}$ to terminate the reaction.

5'- and $3^{\prime}-R A C E$

5'- and 3'-RACEs were performed according to the instructions of BD SMART ${ }^{\mathrm{TM}}$ RACE cDNA Amplification Kit (BD science, USA). The Gene-Specific Primers (GSPs) were: 3'-RACE GSP: 5'-GTGTCTGC AACCTACACCACAGCTC-3', 5'-RACE GSP:5' - AGTGGTTAACGAATCCGA CCGAGAA -3'.

\section{PCR-RFLP}

The DNA from the F2 pigs was used as a template to perform PCR with primers: 5'-AGTACAAATATGATACTTGC-3' (forward primer 2), 5'-ACTGAGGAATC CTTTTAG -3'(reverse primer 2). The PCR product size is $333 \mathrm{bp}$. The $25 \mu$ reaction system was: $2.0 \mu \mathrm{DNA}(100 \mathrm{ng}), 2.5 \mu \mathrm{l} 2 \mathrm{mM}$ mixed dNTPs, $2.5 \mu \mathrm{l} 10 \times \mathrm{Taq}$ DNA polymerase buffer, $2.5 \mu 125 \mathrm{mM} \mathrm{MgCl}, 1.0 \mu \mathrm{l} 20 \mu \mathrm{M}$ forward primer, $1.0 \mu \mathrm{l} 20 \mu \mathrm{M}$ reverse primer, 1.0 units of Taq DNA polymerase (1U/1 $\mu$ l) (JINMEI,BIOTECH), and $12.5 \mu \mathrm{l}$ sterile water. PCRwas run as follows: $94^{\circ} \mathrm{C}$ for $4 \mathrm{~min}$, followed by 35 cycles of $94^{\circ} \mathrm{C}$ for $50 \mathrm{~s}, 60^{\circ} \mathrm{C}$ for $50 \mathrm{~s}, 72^{\circ} \mathrm{C}$ for $1 \mathrm{~min}$, then $72^{\circ} \mathrm{C}$ extension for 10 min, finally $4^{\circ} \mathrm{C}$ to terminate reaction. The $20 \mu \mathrm{l}$ PCR-RFLP reaction volume was: 
$17 \mu \mathrm{l}$ PCR product, $1 \mu \mathrm{l} \mathrm{TaqI}(5 \mathrm{U}), 2 \mu \mathrm{l} 10 \times$ buffer. The mixture was incubated in an air incubatorat $37^{\circ} \mathrm{C}$ for $4 \mathrm{~h}$, then the genotypes were analysed on the agarose gel $(2 \%)$ containing ethidium bromide.

\section{Statistical analysis}

The association analysis between genotypes and traits was performed with the least square method (GLM procedure, SAS version 8.0) (Liu, 1998). Both additive and dominance effects were estimated using REG procedure of SAS version 8.0, where the additive effect was denoted as $-1,0$ and 1 for $\mathrm{AA}, \mathrm{AB}$ and $\mathrm{BB}$, respectively, and the dominance effect was denoted as $1,-1$ and 1 for $\mathrm{AA}$, $\mathrm{AB}$ and $\mathrm{BB}$, respectively. The model used to analyse the data was assumed to be:

$$
\mathrm{Yijk}=\mu+\mathrm{Si}+\mathrm{Fj}+\mathrm{Gk}+\mathrm{bijkXijk}+\text { eijk }
$$

where: Yijk - the observation of the trait; $\mu$ - the least square mean; $\mathrm{Si}$ - the effect of its sex ( $i=1$ for male or 2 for female); $F j$ - the effect of its family ( $j=2000$ or 2003); Gk - the effect of its genotype $(\mathrm{k}=\mathrm{AA}, \mathrm{AB}, \mathrm{BB})$; bijk - the regression coefficient of the slaughter weight; Xijk - the slaughter weight; eijk - the random residual.

\section{RESULTS AND DISCUSSION}

$m R N A$ differential display. From the mRNA differential display, one mRNA, nominated as mRNA2, was found to be almost not expressed in the Longissimus dorsi muscle of Meishan pigs, while it was over-expressed in the Longissimus dorsi muscle of Large White pigs as shown in Figure 1.

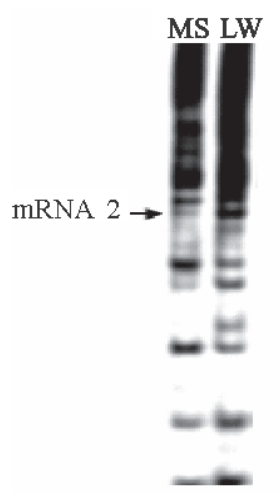

Figure 1. The differential expression analysis of mRNA2. The arrow indicates the cDNA profile for the mRNA2 on a polyacrilamide gel of $8 \%$, stained with silver nitrate. MS - Meishan sample; LW - Large White sample 
Semi-quantitative RT-PCR. The differentially expressed gene band was recovered from gel and used as the template for the re-amplification, which was performed with the respective oligo(dT) primer and the arbitrary primers used in the mRNA differential display. The resulting PCR product was $343 \mathrm{bp}$. This was in agreement with the result of the mRNA differential display. The purified PCR product was then cloned into the T-vector and the recombinant plasmid was sequenced. Semi-quantitative RT-PCR was then conducted using the EST specific primers and the results are presented in Figure 2.
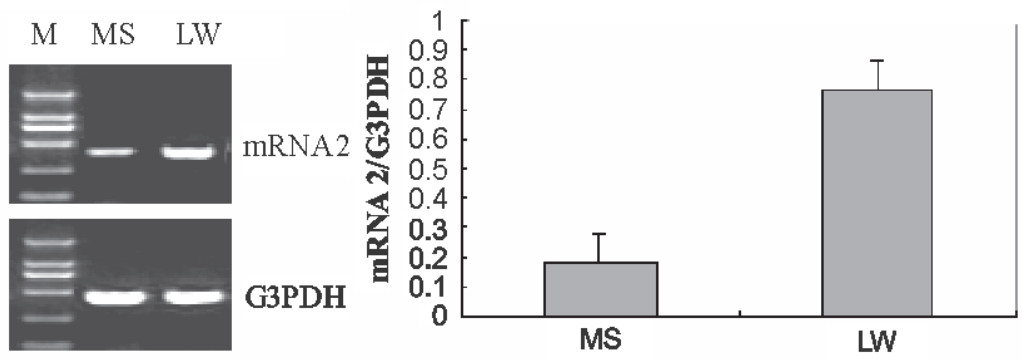

Figure 2. The Semi-quantitative RT-PCR analysis of mRNA2 on the agarose gel of $1 \%$ stained with ethidium bromide. MS - Meishan sample; LW - Large White sample

Semi-quantitative RT-PCR results indicated that mRNA2 was over-expressed in the Longissimus dorsi muscle of Large White pigs and weakly expressed in the Longissimus dorsi muscle of Meishan pigs. This also coincided with the result of mRNA differential display.

RACE and sequence analysis. Through 5'-RACE, one PCR product of $1546 \mathrm{bp}$ was obtained. The 3'-RACE product was $249 \mathrm{bp}$. These products were then cloned to T-vector and sequenced. Taken together, a 1684-bp cDNA complete sequence was finally obtained. The nucleotide sequence analysis using the BLAST software at NCBI server (http://www.ncbi.nlm.nih.gov/BLAST) revealed that this mRNA was not homologous to any of the known porcine genes and it was then deposited into the GenBank database (Accession number: AY864618). The sequence prediction was carried out using the GenScan software and results revealed that the this mRNA is a no-coding mRNA.

Polymorphism. Based on the sequence of mRNA2, primers (forward primer2 and reverse primer2)were used to amplify the DNA of Large White and Meishan and the products were then cloned into PMD18-T vector and sequenced bidirectionally with the commercial fluorometric method. One A-G mutation was found at the position of $490 \mathrm{bp}$. This leaded to mutation of one TaqI restriction site. This was confirmed by PCR -TaqI-RFLP (Figure 3). 


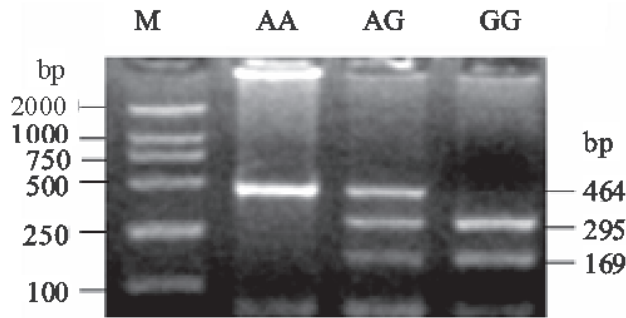

Figure 3. The polymorphism analysis on mRNA 2 by PCR - TaqI-RFLP. AA: 464 bp; AG: 464 bp + 295 bp + 169 bp; GG: 295 bp +169 bp

Subsequently, PCR -Dra I-RFLP were performed using the DNA from 225 unrelated animals belonging to six swine populations including Large White, Landrace, Meishan, Bamei, Tongcheng and Huainan. Results revealed that frequency of $\mathrm{G}$ allele is predominant both in Chinese indigenous and European pig breeds: Large White ( 0.90), Landrace (1.00), Meishan (0.85), Bamei (0.88), Tongcheng (0.63) and Huainan (0.68), but Chinese indigenous pig breeds have the obvious higher frequency of A allele than European pig breeds: Large White (0.10), Landrace (0.00), Meishan (0.15), Bamei (0.12), Tongcheng (0.37) and Huainan (0.32). This indicated that Chinese indigenous pig breeds and European pig breeds displayed obvious genotype and allele frequency differences at this A-G mutation locus (Table 3).

Table 3. Allele frequency and genotype of TaqI polymorphic locus in different pig breeds

\begin{tabular}{|c|c|c|c|c|c|c|}
\hline \multirow{2}{*}{ Breed } & \multirow{2}{*}{$\begin{array}{c}\text { Number of } \\
\text { pigs }\end{array}$} & \multicolumn{3}{|c|}{ Genotype } & \multicolumn{2}{|c|}{ Allele frequency } \\
\hline & & $\mathrm{AA}$ & $\mathrm{AG}$ & GG & $\mathrm{A}$ & G \\
\hline Large White & 40 & 0 & 8 & 32 & 0.10 & 0.90 \\
\hline Landrace & 40 & 0 & 0 & 40 & 0.00 & 1.00 \\
\hline Meishan & 40 & 0 & 12 & 28 & 0.15 & 0.85 \\
\hline Bamei & 40 & 2 & 14 & 24 & 0.12 & 0.88 \\
\hline Tongcheng & 40 & 2 & 26 & 12 & 0.37 & 0.63 \\
\hline Huainan & 25 & 0 & 16 & 9 & 0.32 & 0.68 \\
\hline
\end{tabular}

Association analyses. From the association analysis results it can be seen that pigs with GG genotype have higher $\mathrm{pH}(\mathrm{LD})(+0.088), \mathrm{pH}(\mathrm{BF})(+0.060), \mathrm{pH}$ (SC)(+0.040), but have lower MCV (LD) (-0.813\%) than pigs with AG genotype $(\mathrm{P}<0.05)$. The pigs with GG genotype also have greater DLR $(+0.985 \%)$ than pigs with AA genotype $(\mathrm{P}<0.05)$. On the contrary, pigs with AA genotype have more WHC $(+1.379 \%)$ than pigs with GG genotype $(\mathrm{P}<0.05)$. The pigs with AG and GG genotypes have significantly higher ELMP $(+0.527 \%$ and $+0.529 \%)$ than pigs with AA genotype $(\mathrm{P}<0.05)$. 
From the polymorphism analysis (Table 4), it can be seen that Chinese indigenous pig breeds and European pig breeds displayed obvious genotype and allele frequency differences at this A-G mutation locus. Results revealed that frequency of A allele is predominant in Chinese indigenous pig breeds than European pig breeds. Combining to the results of association analysis: GG genotype have significantly higher DLR, significantly lower WHC and significantly greater ELMP than pigs with AA genotype. These results agree to the differences of two kinds of pigs: Chinese indigenous pig breeds often have low lean rate, but have better meat quality. European pig breeds possess the good achievements in high lean rate, worse meat quality.

Table 4. Association analyses between the different phenotypes of mRNA2 at the TaqI polymorphic locus and the traits

\begin{tabular}{lcrrrr}
\hline \multirow{2}{*}{ Trait } & \multicolumn{3}{c}{ Genotype $(\mu \pm \mathrm{SE})$} & \multicolumn{2}{c}{ Effect $(\mu \pm \mathrm{SE})$} \\
\cline { 2 - 6 } & \multirow{2}{*}{$A A(86)$} & $A G(152)$ & $G G(62)$ & $\begin{array}{c}\text { additive } \\
\text { effect }\end{array}$ & $\begin{array}{c}\text { dominance } \\
\text { effect }\end{array}$ \\
\hline $\mathrm{pH}(\mathrm{LD})$ & $6.326 \pm 0.034$ & $6.263 \pm 0.025^{\mathrm{a}}$ & $6.352 \pm 0.013^{\mathrm{b}}$ & $-0.001 \pm 0.028$ & $0.045 \pm 0.018$ \\
$\mathrm{pH}(\mathrm{BF})$ & $6.363 \pm 0.017$ & $6.361 \pm 0.016^{\mathrm{a}}$ & $6.422 \pm 0.010^{\mathrm{b}}$ & $0.030 \pm 0.020$ & $0.014 \pm 0.012$ \\
$\mathrm{pH}(\mathrm{SC})$ & $6.421 \pm 0.029$ & $6.405 \pm 0.015^{\mathrm{a}}$ & $6.445 \pm 0.009^{\mathrm{b}}$ & $0.012 \pm 0.019$ & $0.014 \pm 0.011$ \\
$\mathrm{DLR}$ & $6.431 \pm 0.431^{\mathrm{a}}$ & $6.564 \pm 0.202$ & $7.416 \pm 0.447^{\mathrm{b}}$ & $0.066 \pm 0.468$ & $-0.459 \pm 0.291$ \\
WHC & $91.336 \pm 0.588^{\mathrm{a}}$ & $91.097 \pm 0.594$ & $89.957 \pm 0.594^{\mathrm{b}}$ & $-0.119 \pm 0.623$ & $0.629 \pm 0.387$ \\
MCV (LD) & $18.916 \pm 0.436$ & $19.646 \pm 0.321^{\mathrm{a}}$ & $18.833 \pm 0.146^{\mathrm{b}}$ & $-0.041 \pm 0.338$ & $-0.385 \pm 0.210$ \\
ELMP & $4.223 \pm 0.176^{\mathrm{a}}$ & $4.750 \pm 0.089^{\mathrm{b}}$ & $4.752 \pm 0.063^{\mathrm{b}}$ & $0.086 \pm 0.127$ & $0.009 \pm 0.079$ \\
\hline
\end{tabular}

note: data in the table are least square means \pm standard error; values in each line with lower case superscripts are significantly different at $\mathrm{P}<0.05$; additive effect $=(\mathrm{GG}-\mathrm{AA}) / 2$; dominance effect $=$ $\mathrm{AB}-(\mathrm{AA}+\mathrm{GG}) / 2 ; *$ means significant at $\mathrm{P}<0.05 ; * *$ means significant at $\mathrm{P}<0.01$

The pig industry is now actively using this information to improve the pig production by marker assisted selection (MAS). So it is of outmost importance to find more candidate genes or DNA molecular markers in order to improve pig production. From our results, we found the polymorphism of the TaqI locus of this porcine mRNA significantly affected some important traits which were related to carcass traits and meat quality traits. This indicates that this polymorphic locus of porcine mRNA is a valuable marker deserved to be applied to the marker assistant selection (MAS) in pig breeding.

In spite that gene prediction has show that this novel porcine mRNA is not protein-coding gene,we still find some ORFs in this novel porcine mRNA using the ORF Finder (Open Reading Frame Finder) (http://www.ncbi.nlm.nih.gov/gorf/ gorf.html). We do not know which ORF represents its protein-coding region. 


\section{CONCLUSIONS}

Under current condition, we only can give below conclusions or hypothesis:

1. This porcine mRNA is exactly a uncoding gene,

2. This porcine mRNA is exactly a protein-coding gene but we still have not obtain its full-legth,

3. Since this porcine mRNA is significantly differentially expressed in the Longissimus muscle tissues from Meishan and Large White pigs and is significantly associated with some carcass traits and meat quality traits, this porcine mRNA must have some important functions.

\section{REFERENCES}

Liang P., Averboukh L., Pardee A.B., 1993. Distribution and cloning of eukaryotic mRNAs by means of differential display: Refinements and optimization. Nucl. Acid. Res. 21, 3269-3275

Liang P., Pardee A.B., 1992. Differential display of eukaryotic messenger RNA by means of the polymerase chain reaction. Science $257,967-971$

Liu B.H., 1998. Statistical Genomics: Linkage, Mapping, and QTL Analysis. LLC: CRC Press, pp. 404-409

Liu G.Y., Xiong Y.Z., 2007. Isolation, sequence analysis and expression profile of a novel porcine gene, NIP7, differentially expressed in the Longissimus dorsi muscle tissues from Meishan, Meishan x Large White cross and Large White pigs. Mol. Biol. Rep. 344, 213-219

Liu G.Y., Xiong Y.Z., Deng C.Y., 2005a. Isolation, identification of differentially expressed sequence tags in the backfat tissue from Meishan, Large White and Meishan $\times$ Large White cross pigs. Agr. Sci. China 4, 101-105

Liu G.Y., Xiong Y.Z., Deng C.Y., 2005b. Isolation, sequence analysis and expression profile of a novel swine gene differentially expressed in the Longissimus dorsi muscle tissues from Landrace $\times$ Large White cross-combination. Acta Biochim. Biophys. Sinica 37, 186-191

Liu G.Y., Xiong Y.Z., Deng C.Y., Zuo B., Zhang J.H., 2004. Comparison of gene expression patterns in Longissimus dorsi of pigs between the high-parent heterosis cross combination Landrace $\times$ Large White and the mid-parent heterosis cross combination Large White $\times$ Meishan. Asian-Austr. J. Anim. Sci. 17, 1192-1196

Pan P.W., Zhao S.H., Yu M., Xiong T.A., Li K., 2003. Identification of differentially expressed genes in the Longissimus dorsi tissue between Duroc and Erhualian pigs by mRNA differential display. Asian-Austr. J. Anim. Sci. 16, 1066-1070

Sambrook J., Fritsch E.F., Maniatis T., 1989. Molecular Cloning: A Laboratory Manual. $2^{\text {nd }}$ Edition. New York: Cold Spring Harbor Laboratory Press

Xiong Y.Z., Deng C.Y., 1999. Principle and Method of Swine Testing (in Chinese). Chinese Agricultural Press, Beijing

Yamazaki M., Saito K., 2002. Differential display analysis of gene expression in plants. Cell Mol. Life Sci. 59, 1246-1255 